Recorregut de recerca geològica i mineralògica per les comarques de la Conca de Barberà i del Baix Camp: des de les masies de Poblet a la Pena, a la Mina Atrevida, al Pont de Castellfollit i a Prades

Josep Maria Mata-Perelló

Joaquim Sanz Balagué

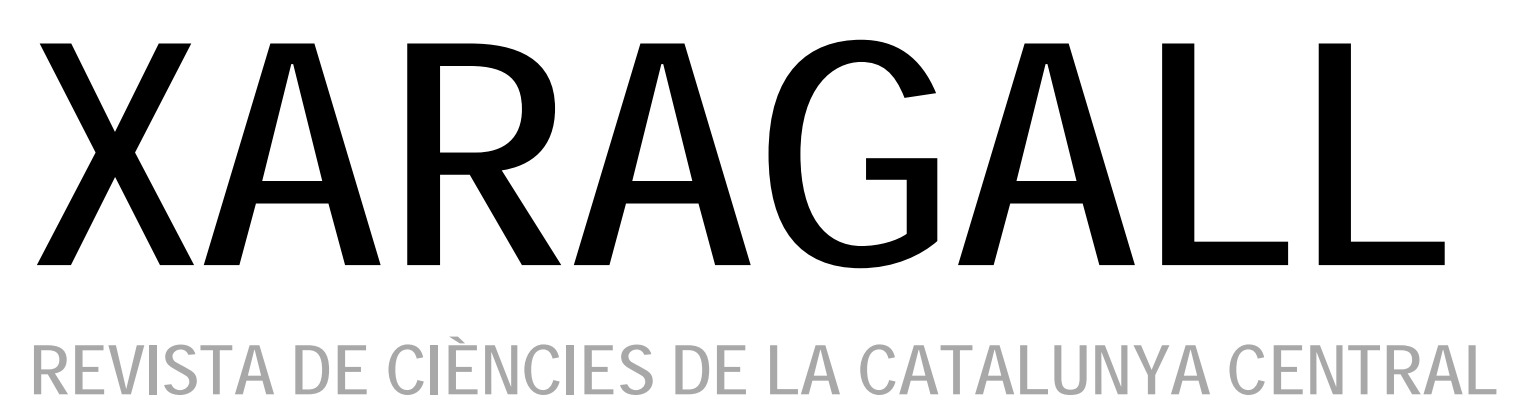

n. 4

ABRIL 2015 


\title{
RECORREGUT DE RECERCA GEOLÒGICA I MINERALÒGICA PER LES COMARQUES DE LA CONCA DE BARBERÀ I DEL BAIX CAMP: DES DE LES MASIES DE POBLET A LA PENA, A LA MINA ATREVIDA, AL PONT DE CASTELLFOLLIT I A PRADES
}

\author{
Josep Maria Mata-Perelló \\ Museu de geologia Valentí Masachs, Escola Politècnica Superior d'Enginyeria de Manresa \\ (EPSEM), Universitat Politècnica de Catalunya · BarcelonaTech (UPC), 08272 Manresa, Spain
}

Joaquim Sanz Balagué

Departament d'Enginyeria Minera i Recursos Naturals (EMRN), Escola Politècnica Superior d'Enginyeria de Manresa (EPSEM), Universitat Politècnica de Catalunya . BarcelonaTech (UPC), 08272 Manresa, Spain

Paraules clau: Sistema Mediterrani, Patrimoni miner

\begin{abstract}
Resum
Itinerari realitzat el 30 de maig de 2014. En aquesta ocasió, es realitzarà un recorregut geològic i mineralògic a través de diferents indrets de la comarca de la Conca de Barberà, primer entre les Masies de Poblet (de l'Espluga de Francolí) anant cap a les immediacions del Monestir de Poblet i posteriorment cap a la Mina Atrevida i els voltants de Castellfollit, anant després cap a Prades, per on finalitzarà, dintre ja de la comarca del Baix Camp.

El recorregut de l'itinerari s'iniciarà a la zona de contacte entre la Depressió Geològica de I'Ebre, i el Sistema Mediterrani (Serralada Prelitoral Catalana) cap a les immediacions de les Masies de Poblet; tot i així, la pràctica totalitat del recorregut de l'itinerari es durà a terme per I'esmentada Serralada Prelitoral Catalana, una de les sots-unitats que integren el Sistema Mediterrani, una de les unitats geològiques que constitueix el nostre país.
\end{abstract}

Així, al llarg de tot el recorregut de l'itinerari, anirem trobant afloraments dels materials paleozoics (fonamentalment del Carbonífer) que constitueixen aquesta serralada i tanmateix dels terrenys mesozoics del Triàsic.

Per altra banda, la major part del recorregut de l'itinerari, tindrà terme dintre de la comarca de la Conca de Barberà, tot i que els darrers trams del recorregut, ja es faran per la comarca del Baix Camp.

Xaragall.2015 n.4 | Recorregut de recerca geològica i mineralògica per les comarques de la Conca de 


\section{Objectius fonamentals}

Els objectius fonamentals que es pretenen aconseguir en aquest itinerari, es poden concretar en els següents aspectes generals:

1. Observació i descripció dels materials paleozoics (del Carbonífer, quasi sempre), i dels mesozoics (fonamentalment del Triàsic,; tant del Buntsandsteim com del Muschelkalk), que constitueixen la Serralada Prelitoral, dintre de la comarca de la Conca de Barberà i del Baix Camp, a través dels indrets pels quals discorre el recorregut de l'itinerari. Aquests afloraments pertanyen a la vorera oriental de la Taula de Prades (on afloren, per aquests indrets exclusivament els materials mesozoics del Triàsic i els paleozoics del Carbonífer), situada entre I’Espluga de Francolí i la Mina Atrevida.

2. Observació i descripció dels materials cenozoics (exclusivament del paleogen) de la Depressió Geològica de l'Ebre (i més concretament de la seva Depressió Central), els quals constitueixen part del subsòl de la zona de la comarca de la Conca de Barberà, per la qual discorre el present itinerari, entre I’Espluga de Francolí i les Masies de Poblet. Aquests materials pertanyen en bona part al Grup Pontils, tot i que es troben recoberts per terrenys detrítics posteriors del Pleistocè i de l'Holocè.

3. Observació de les estructures locals d'aquests materials, al llarg del recorregut de I'itinerari, i de les relacions existents entre les dues unitats geològiques acabades d'esmentar, entre la Depressió Geològica de l'Ebre i el Sistema Mediterrani.

4. Observació, de les diferents mineralitzacions que anirem trobant al llarg del recorregut; concretament de les següents, d'acord amb el sentit de la marxa:

4A) de les mineralitzacions supergèniques $d^{\prime}$ alteració de pirites, que trobarem quasi a l'inici del recorregut, prop de les Masies de Poblet, al camí que ascendeix cap a la Pena.

4B) les mineralitzacions filonianes de Ba-Pb-Zn, situades a la Mina Atrevida de Vimbodí. Aquestes mineralitzacions es troben a la Serralada Prelitoral Catalana, i encaixen entre els materials paleozoics del Carbonífer de la Taula de Prades.

4C) i si s'escau de les mineralitzacions filonianes de Baritina, que veurem a la Mina del Tossal de la Baltasana, dintre del terme de Prades. També es situen a la Serralada Prelitoral Catalana, i encaixen entre els materials paleozoics del Carbonífer de la Taula de Prades.

5. Observació dels diferents explotacions mineres que anirem trobant al llarg del recorregut de l'itinerari.

6. Observació dels diferents trets relacionats amb la geologia ambiental, que anirem trobant al llarg del recorregut

7. Observació del Patrimoni Geològic i Miner que anirem trobant al llarg del recorregut. En concret, farem esment del Patrimoni Miner relacionat amb les antigues explotacions de la Mina Atrevida 


\section{Antecedents}

Pel que fa al recorregut del present itinerari, sols tenim coneixement de l'existència de diferents itineraris nostres, els quals discorren per aquests indrets, tot i que en cap cas ho fan en el sentit d'aquest recorregut. Entre ells farem esment dels següents: MATA-PERELLÓ (1997a, 1997b, 1997c, 1999a, 1999b, 2000, 2002, 2003, 2004, 2010 i 2011). Un treball molt recent i alhora força interessant és el de MARTíNEZ (2014).

Pel que fa a la descripció de les mineralitzacions situades a les comarques per les quals discorre l'itinerari, farem esment d'un altre treball nostre, relatiu al conjunt de les mineralitzacions catalanes. Es tracta de MATA-PERELLÓ (1991). Tanmateix farem esment de I'important treball de MELGAREJO (1992), corresponent a les mineralitzacions de diverses comarques tarragonines, i entre elles la Conca de Barberà i el Baix Camp.

I, finalment, pel que fa a l'estructura geològica de la zona per la qual discorre l'itinerari, farem esment de dos treballs referits al conjunt dels Països Catalans. es tracta de GUIMERÀ et altri (1992), així com de RIBA et altri (1976). També ens referirem a dues publicacions de I'IGME (1973a i 1973b), relatius a dues fulles del Mapa Geológico de España (a escala 1:50.000).

Tots aquests treballs referenciats, i d'altres, figuren esmentats per ordre alfabètic a l'apartat dedicat a les REFERÈNCIES BIBLIOGRÀFIQUES, al qual ens remetem.

\section{Recorregut de l'itinerari}

El recorregut de l'itinerari començarà a la població de l'Espluga de Francolí. Després, el recorregut es dirigirà cap a les immediates Masies de Poblet, on es farà la primera aturada, a peu de carretera. En aquest tram, el recorregut s' haurà fet per la carretera local TV - 7007.

Des de prop d'aquest lloc, s'agafarà el camí de terra que ascendeix cap als paratges de la Pena i del Pic de l'Àliga, per tal d'anar a la Mina Atrevida. En aquest tram, per on caldrà conduir amb forta cura (ja que aquest camí no sempre es troba en bones condicions), es faran diverses aturades, quasi sempre entorn a les antigues explotacions mineres. En arribar a les immediacions del Coll de l'Àguila, es faran diverses aturades i recorreguts a peu, entorn de la Mina Atrevida.

Després de realitzar aquesta darrera aturada es baixarà cap a Castellfollit, per tal d'efectuar una nova parada. Aquest tram es troba en males condicions i possiblement serà millor retornar als inicis del camí, prop de les Masies de Poblet i del Santuari, per tal d'arribar per carretera a l'indret de Castellfollit, utilitzant la ruta $\mathrm{T}-700$.

Posteriorment, el recorregut es dirigirà cap a la població de Prades, entrant a la comarca del Baix Camp. En aquest tram, es circularà per la carretera $T-700$. Abans d'arribar-hi es realitzarà una nova parada al Tossal de la Baltasana, efectuant-se la darrera aturada a l'entrada del poble de Prades. En aquest mateix indret finalitzarà el recorregut d'aquest itinerari. Tot i així, abans d'arribar-hi, possiblement es farà una nova aturada.

Xaragall.2015 n.4 | Recorregut de recerca geològica i mineralògica per les comarques de la Conca de 


\section{Advertiments previs}

Com en altres recorreguts de RECERCA GEOLÒGICA I MINERALÒGICA... si es disposa del temps suficient, poden efectuar-se passant per totes les parades i filloles. En cas contrari, recomanem prescindir de les anomenades PARADES - CONDICIONALS.

També recomanem de cercar la informació més adient, sobre els trams a recórrer mitjançant camins de terra, o de pista. Aquest és el cas del camí que ens ha de conduir cap a la Mina Atrevida. També cal considerar I'estat del camí de baixada, des de la Mina Atrevida fins a les immediacions de Castellfollit: i si s'escau, es donarà la volta pel Monestir de Poblet.

Per d'altra banda, recomanem tenir una cura extrema de la NATURA, evitant qualsevol forma d'agressió sobre ella, o de fer-n'hi un mal ús del que en ofereix la nostra mare Terra.

\section{Descripció de l'itinerari}

Com de costum, estructurarem el recorregut de l'itinerari en una sèrie de PARADES, que tot seguit anirem veient. En cadascuna d'aquestes aturades farem un breu comentari (geològic 0 mineralògic, segons s'escaigui). En cada cas, indicarem, entre parèntesi, el full topogràfic on es troba l'aturada.

Per altra banda, cal dir que el recorregut de l'itinerari s'inclourà dintre dels dos següents fulls, del "Mapa Topográfico Nacional", realitzats a l'escala 1:50.000 per I'"Instituto Geografico y Catastral de España": 417 (també dit de I'Espluga de Francolí), 418 (també denominat de Montblanc) i 445 (o de Cornudella).

A continuació, anirem veient les diverses aturades que composen el recorregut del present itinerari:

\subsection{Parada 1 - CONDICIONAL. FONT DE FERRO DEL BARRANC DE SANT BENET, (Masies de Poblet, terme municipal de I'Espluga de Francolí, comarca de la Conca de Barberà). (Full 417).}

L'inici del recorregut el realitzarem a la població de l'Espluga de Francolí, per tal d'agafar la carretera que es dirigeix cap a les Masies de Poblet, la TV - 7007. Poc abans d'arribar-hi, es troba el barranc de Sant Benet, on ens caldrà fer la present parada. Així, des de la sortida, s'haurà efectuat un recorregut aproximat d'uns $2 \mathrm{Km}$.

Bona part del recorregut l'haurem realitzat dintre de la Depressió Geològica de I'Ebre, tot i que els materials cenozoics del Paleogen que la constitueixen es troben recoberts per terrenys detrítics del Pleistocè i de l'Holocè.

En aquest lloc es troben unes concentracions ferruginoses, molt secundàries, formades per la precipitació d'òxids de ferro (i de sulfats del mateix metall), transportades per les aigües del Barranc de Sant Benet. Aquestes sals de ferro, procedeixen de l'alteració d'unes pirites situades més amunt, dintre dels afloraments del Carbonífer. El mineral més abundant d'aquestes concentracions és la GOETHITA (terrosa, d'aspecte limonític).

Xaragall.2015 n.4 | Recorregut de recerca geològica i mineralògica per les comarques de la Conca de 


\subsection{Parada 2. PRIMER REVOLT DEL CAMÍ DE LA PENA, (Monestir de Poblet, terme de Vimbodí, comarca de la Conca de Barberà). (Full 417).}

Des de la parada anterior, cal agafar el camí que condueix al paratge de La Pena. Aquest camí es troba a menys de $50 \mathrm{~m}$ de la parada anterior, i a menys de $1 \mathrm{Km}$ del monestir. En arribar a la primera corba del camí, cal fer la present parada.

Aquest recorregut, I' haurem efectuat sempre dintre de la Serralada Prelitoral Catalana, on hem entrat a la parada anterior.

En aquest lloc es troba un aflorament de nivells piritosos foscos (possiblement del Silurià). Sobre aquests nivells, s'ha generat una intensa alteració de la PIRITA, formant-se diversos sulfats com: FERROHEXAHIDRITA, MELANTERITA i SIDEROTÍL.

També s'ha originat, la presència d'abundant GOETHITA (en forma de LIMONITA). Igualment hi ha presència de LEPIDOCROCITA (sols possible de reconèixer per mètodes de difracció de $\mathrm{RX}$ ). Per d'altra banda, cal fer esment de la presència d'indicis de GRAFIT, entre els materials piritosos paleozoics.

Per altra banda, cal fer esment de la presencia d'unes roques intrusives, de caràcter diorític, entre els nivells de les pissarres que hem esmentat.

\subsection{PARADA 3. CATA MINERA DEL CAMí FORESTAL DE LA PENA, (Monestir de Poblet, (terme municipal de Vimbodí, comarca de la Conca de Barberà). (Full 417).}

Des de la parada anterior, cal continuar pel camí que ascendeix cap a la Pena. A poca distància de l'altra parada (a menys de $100 \mathrm{~m}$ ), es troba un trencall, per la dreta. Seguint-lo, en uns altres $100 \mathrm{~m}$, s' arriba a una antiga prospecció minera. Aquí caldrà fer aquesta nova parada. Aquest indret es troba a uns 15 metres per sobre del de l'anterior aturada.

Com a la parada anterior, aquest recorregut, I'haurem efectuat sempre dintre de la Serralada Prelitoral Catalana. Així, haurem trobat afloraments dels materials esmentats anteriorment del Silurià, amb pissarres negres. Aquests materials afloren per arreu, per on ens trobem nosaltres.

En aquest lloc, es troba un aflorament de nivells de pissarres negres silurianes, que contenen presència de sulfurs de ferro com: PIRITA, MARCASSITA, MELNIKOWITA i PIRROTINA (molt minoritària).

Per altra banda, per l'alteració d'aquests sulfurs s'han format els següents òxids i sulfats minerals: GOETHITA (en forma de la roca LIMONITA), GUIX, JAROSITA, NATROJAROSITA i MELANTERITA. De forma molt més minoritari, entre els òxids de ferro de la limonita, cal dir que també hi ha LEPIDOCROCITA i SIDEROGEL, difícilment identificables a simple vista. 


\subsection{Parada 4. IMMEDIACIONS DE LA PENA, (Monestir de Poblet, terme municipal de Vimbodí, comarca de la Conca de Barberà). (Full 417).}

Des de la parada anterior, cal continuar pel camí que ascendeix cap al Paratge de la Pena. En aquest recorregut, es passa per un tram de direcció única, de prop de $4 \mathrm{Km}$. Després, śarriba a la cruillla dels dos trams (el ascendent i el descendent), amb el brancall que es dirigeix cap a la Pena. En arribar a aquest indret, cal fer una nova aturada, als esmentats $4 \mathrm{Km}$ des de la parada anteriorment realitzada.

En aquest recorregut, des de la parada anterior, es van trobant els materials paleozoics, majoritàriament del Carbonífer, amb freqüents intrusions granítiques. Més amunt, prop de la cruïlla del camí de la Pena, es comencen a trobar els nivells detrítics del Triàsic Inferior (és a dir, del Buntsandsteim), els quals es troben constituïts per nivells de conglomerats quarsosos, els quals són clarament discordants amb tots els anteriors.

Aquests darrers materials es troben discordants sobre els del paleozoic, que hem anat trobant al llarg del recorregut. Per d'altra banda. Per sobre d'aquests terrenys del Buntsandsteim, es fan palesos els relleus carbonatats del Muschelkalk, que també pertanyen al Triàsic.

Des d'aquest indret, es pot gaudir d'una bona observació del Bosc de Poblet, per on estem situats.

\subsection{Parada 5. ROCA TALLADA, ELS FRARES ENCANTATS, (Monestir de Poblet, terme municipal de Vimbodí, comarca de la Conca de Barberà). (Full 417).}

Tot seguit, des de la parada anterior, cal continuar pel tram de de doble direcció, que es dirigeix cap al Puig de l'Àliga. Abans d'arribar-hi (i abans d'arribar al trencall de Rojals), es troba un camí descendent, per la dreta, que es dirigeix cap a la Mina Tacha. En aquest indret, a menys de 0 ' $5 \mathrm{Km}$ de l'anterior, podem fer una nova aturada.

En aquest tram del recorregut, hem anat trobant afloraments dels materials que ja hem vist a I'aturada anterior: els nivells de gresos i conglomerats rogencs, que formen part del Buntsandsteim. Aquests són també els que afloren a l'indret de la present aturada.

En aquest indret, es pot gaudir de la bellesa del paratge de Roca Tallada. Es tracta d'un bloc dels materials del Buntsandsteim, fracturat en quasi dues meitats. (fotografía 1).. 


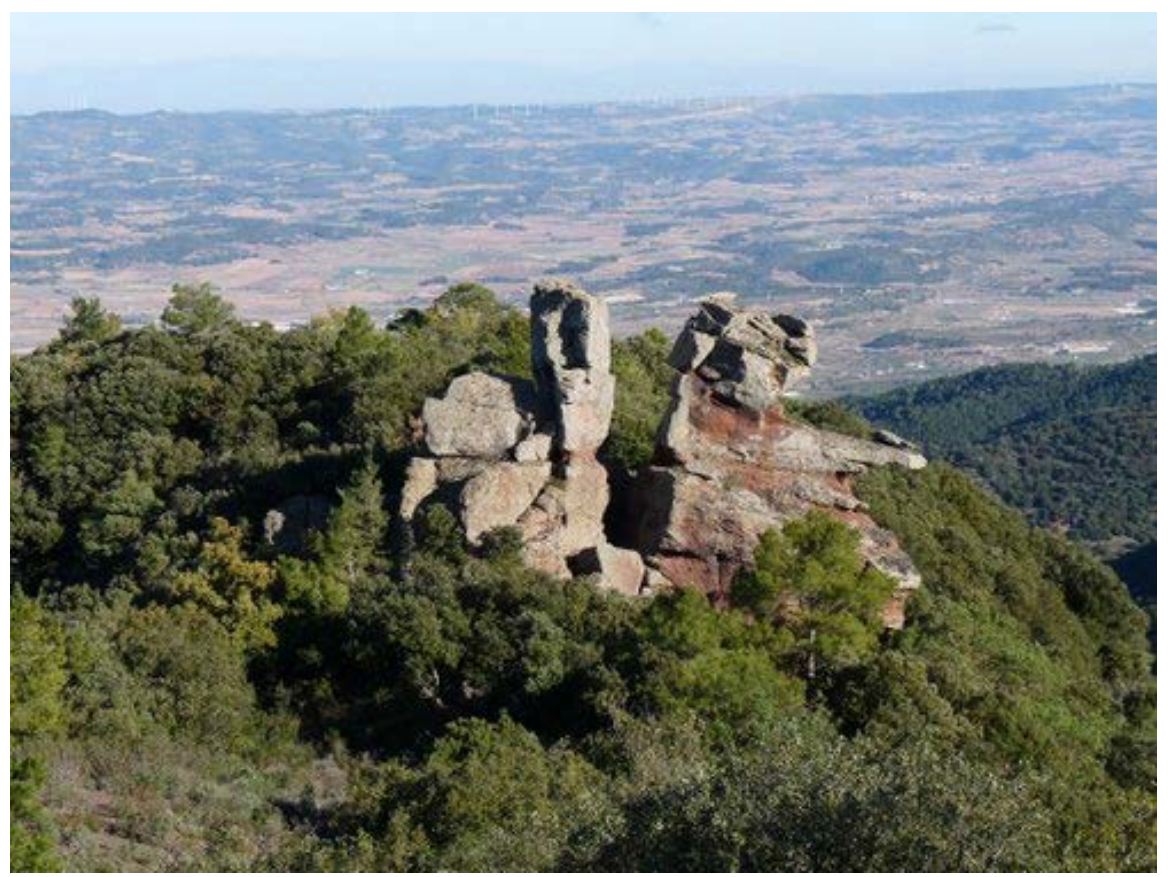

Fotografia 1. Els Frares Encantats

Per altra banda, des d'aquest lloc, també, es pot gaudir d'una bona vista de la Conca de Barberà, dels propers relleus de la Serralada Prelitoral Catalana i dels més llunyans de la plana de la comarca, situada dintre de la Depressió geològica de l'Ebre.

\subsection{Parada 6. MINA TACHA, (Monestir de Poblet, terme municipal de Vimbodí, comarca de la Conca de Barberà). (Full 417).}

Després de fer l'aturada anterior, cal agafar un corriol, per tal de continuar a peu cap a la Mina Tacha. Caldrà anar-hi a peu, doncs el camí es troba en molt mal estat. Després d'un recorregut proper als 10 minuts, s'arriba a les antigues mines.

En aquest recorregut, des de la parada anterior, es van inicialment els materials triàsics del Buntsandsteim. Després, per sota, es tornen a trobar els materials paleozoics, discordants amb els anteriors. De fet, en el camí cap a la mina es va tallant la discordança. Així, per sota de la parada anterior i a la bora del camí, es pot veure el contacte discordant entre els conglomerats basals del Buntsandsteim, i els materials pissarrencs del Carbonífer, que en aquest indret es troben intensament rubefactats, debut a la proximitat dels trams rogencs del Buntsandsteim, els quals es troben per sobre dels mateixos conglomerats.

Més endavant, el camí serpentejant, arriba a les antigues explotacions de la Mina Tacha, també anomenada "galeria Tacha". Aquestes instal-lacions es troben a uns $200 \mathrm{~m}$ al nord del Puig de l'Àliga.

En aquest indret hi ha unes labors mineres, realitzades sobre el denominat Filó Atrevida (que després veurem a l'aturada següent). Aquest filó es troba encaixat entre els materials paleozoics esmentats anteriorment. Es tracta d'una interessant mineralització filoniana, situada sobre una fractura. Alhora, inicialment es tracta també d'una mineralització supergènica associada a sedex.

Xaragall.2015 n.4 | Recorregut de recerca geològica i mineralògica per les comarques de la Conca de 
Entre els minerals presents a l'escombrera, cal fer esment dels següents: PLATA NATIVA, ARGENTITA (molt rara), CALCOPIRITA, GALENA, MARCASSITA, MILLERITA, NIQUELINA (poc abundant), PIRITA, RAMMELSBERGITA (com la niquelina), SKUTTERUDITA (com I'anterior), CALCITA, DOLOMITA, BARITINA (molt abundant, va ésser el mineral explotat) i QUARS.

Tanmateix, es troben força minerals d'alteració, com: GOETHITA (limonítica), ATZURITA, CERUSSITA, HIDROCINCITA, MALAQUITA, ANGLESITA, CABRERITA i TIROLITA, entre altres minerals.

Per altra banda, també es força abundant la presència de PIROLUSITA (tot formant dendrites).

\subsection{Parada 7. MIRADOR DEL PRIMER REVOLT DESPRÉS DEL CAMÍ DE LA MINA TACHA, (Monestir de Poblet, terme municipal de Vimbodí, comarca de la Conca de Barberà). (Full 417).}

Després de realitzar la parada anterior, cal retornar a l'inici del brancall, per tal de continuar cap a la Mina Atrevida. Poc després de la cruïlla, a menys de $50 \mathrm{~m}$, es troba un mirador, on es pot fer aquesta nova parada.

Per altra banda, s'ha tornat a passar la discordança esmentada a la parada anterior, i el mirador es troba sobre els nivells de conglomerats del Buntsandsteim, situats per sota dels nivells de gresos i de calcolutites rogenques, també de l'esmentat tram del Triàsic Inferior.

Des d'aquest indret, i mirant cap a llevant, es pot gaudir d'un bon lloc d'observació dels relleus de la Pena, amb el Triàsic (constituït pel Buntsandsteim, i també pel Muschelkalk Inferior), discordants sobre els afloraments paleozoics.

\subsection{Parada 8. COLL DEL PIC DE L'ÀLIGA, (Monestir de Poblet, terme municipal de Vimbodí, comarca de la Conca de Barberà). (Full 417).}

Després de realitzar la parada anterior, cal continuar amunt pel camí que es va dirigint cap a la Mina Atrevida. En arribar al Coll de l'Àliga, situat per sota del Pic de l'Àliga, podem fer una nova aturada, a uns $2 \mathrm{Km}$ i escaig de l'anterior.

En aquest tram del recorregut, hem continuat trobant els materials triàsics que ja hem vist al recorregut anterior. Tot $\mathrm{i}$ així, en aquest indret es fan palesos els nivells de calcolutites rogenques, que també pertanyen al Triàsic Inferior, al Buntsandsteim. Aquests materials, més tous, són els que es troben ara al coll. De totes formes, aquest coll te un clar component estructural, ja que es troba molt proper a la falla de la Mina Atrevida, com veurem a continuació, a l’aturada següent.

Per altra banda, per sobre d'aquesta materials, al Pic de l'Àliga, es fan palesos uns nivells que pertanyen al triàsic Mig, al Muschelkalk Inferior. Aquests materials més durs (amb nivells carbonatats de calcaries i dolomies) constitueixen el nivells més alts, els cingles del Pic de I'Àliga. (fotografies 2 i 3) 


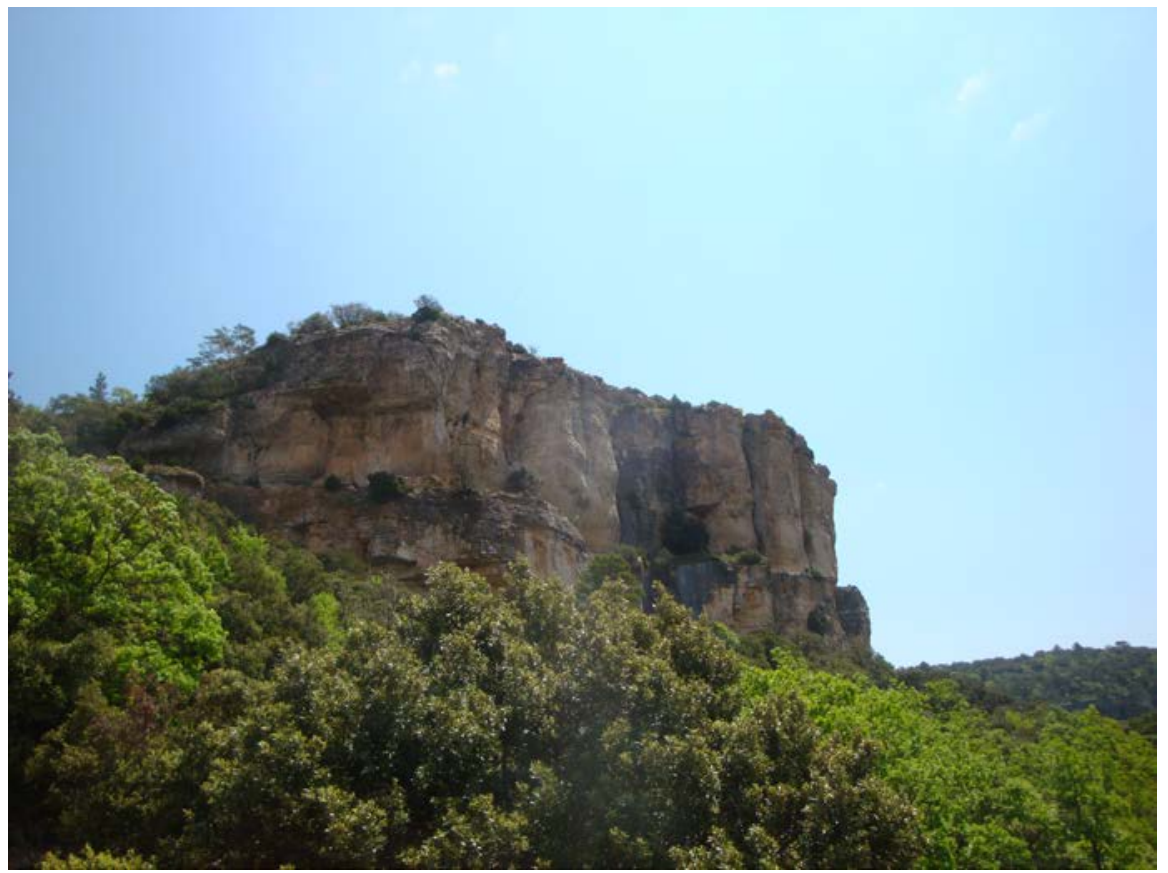

Fotografia 2. Relleus triàsics (del Muschelkalk Inferior) del Pic de l'Àliga. Bosc de Poblet

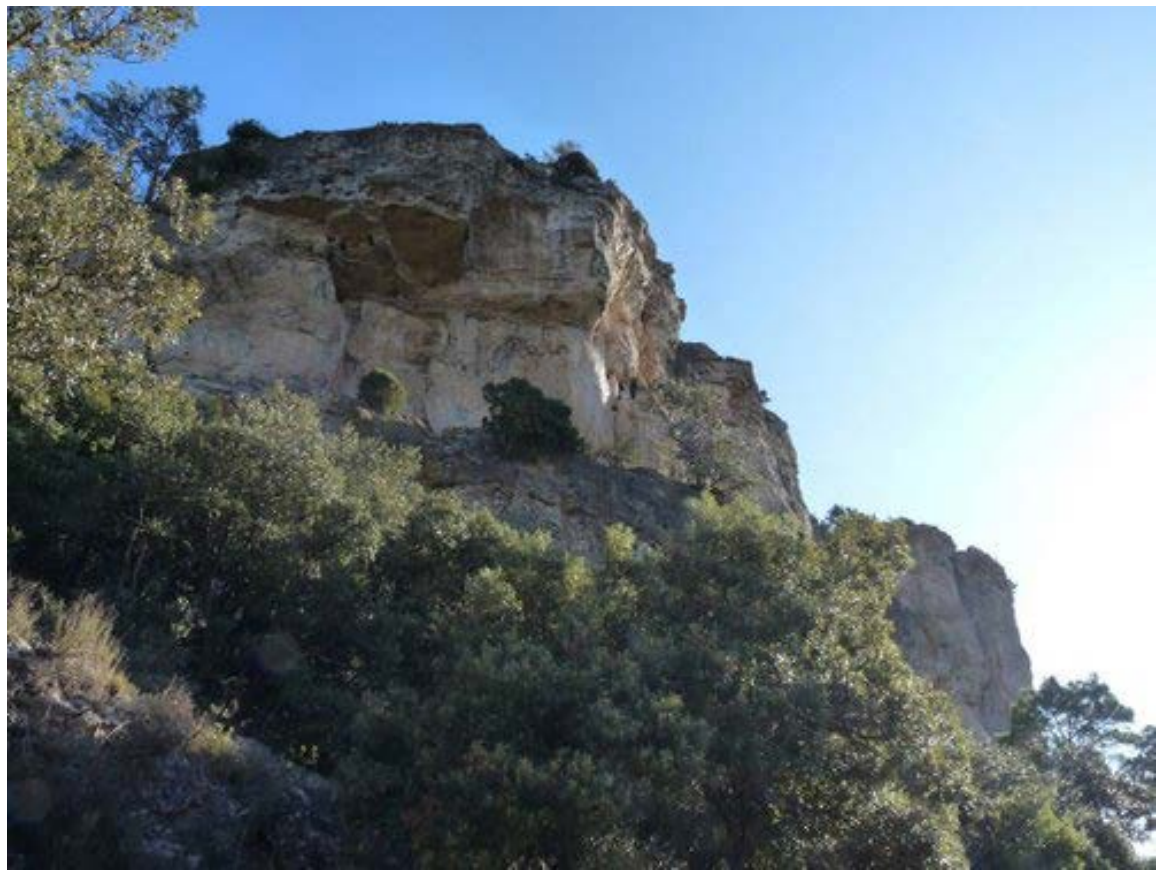

Fotografia 3. Un altre aspecte dels afloraments dels materials carbonatats triàsics, del Musckelkalk Inferior, al Pic de I’Àliga, al Bosc de Poblet

Xaragall.2015 n.4 | Recorregut de recerca geològica i mineralògica per les comarques de la Conca de 


\subsection{Parada 9. CARREGADOR DE LA MINA ATREVIDA ("MALACATE"), (Monestir de Poblet, terme municipal de Vimbodí, comarca de la Conca de Barberà). (Full 417).}

Després de fer l'aturada anterior, cal fer un breu recorregut (a peu) de menys de 50 metres, anant cap a ponent, per sobre del coll. Així, arribarem al conegut "Malacate" de la Mina Atrevida. Aquí farem la present aturada; això si: amb molta cura.

En aquest indret, es pot veure la part superior d'una gran explotació minera. Aquesta està situada sobre un extraordinari filó (l'anomenat Filo Atrevida), eminentment de BARITINA. Té unes dimensions de més de $3 \mathrm{Km}$ de llargada, amb uns $150 \mathrm{~m}$ de profunditat, amb una amplada que oscil.la entre els $0 ` 5$ i els $6 \mathrm{~m}$. La seva direcció es de NNW-SSE, trobant-se verticalitzat. Per d'altra banda, pot dir-se que es troba relacionat amb una fractura, que posa en contacte, a l'indret del Malacate, els materials del Carbonífer, amb els del Triàsic Inferior, per d'altra banda, discordants amb els anteriors.

El filó, encaixa fonamentalment entre paleozoiques del Carbonífer, constituïdes per pissarres i per granits tardihercínics. Per d'altra banda, cal dir que la mineralització es troba associada a paleosuperfícies d'erosió, d'edat triàsica, i arriba a encaixar en aquests darrers materials, a les seves parts més superiors. Posteriorment, la mineralització es va remobilitzar, passant a tindre característiques filonianes.

En relació amb aquesta mineralització, cal dir que existeixen gran nombre d'explotacions d'aquest filó, situades entorn al Pic de l’Àliga. Aquestes explotacions s'han dedicat ocasionalment al benefici de l'Argent; altres vegades a aprofitar la galena; però la major part de les ocasions s' han dedicat a extreure la baritina, el mineral més abundant.

Una d'aquestes explotacions és la denominada "Trinxera", a la qual es pot accedir directament des del Collet de l'Àliga, que és la que ara estem veient, a l'indret de la present aturada. cal dir que cal tindre una gran cura, especialment per les dimensions de l'explotació. (fotografíes 4 i 5).

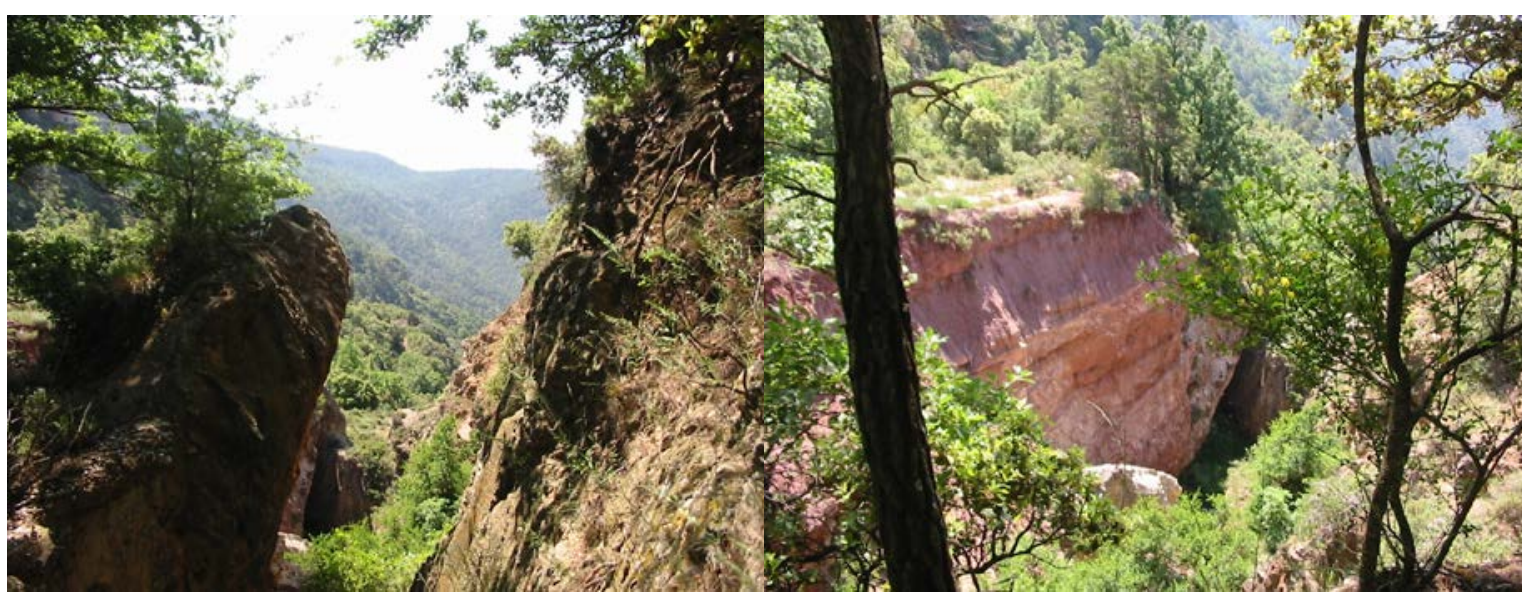

Fotografia 4. Un aspecte del filó explotat. La Trinxera
Fotografia 5. Un aspecte del filo. A la dreta es pot veure I'indret on hi ha la falla. La Trinxera

Xaragall.2015 n.4 | Recorregut de recerca geològica i mineralògica per les comarques de la Conca de Barberà i del Baix Camp: des de les masies de Poblet a la Pena, a la Mina Atrevida, al Pont de Castellfollit i a 
Per altra banda, observant atentament la FOTOGRAFIA 2, que ara reproduïm a continuació, a l'ESQUEMA 1, es pot veure com hi ha una fractura, que s'intueix des d'aquest indret fins al Coll de Rojals.

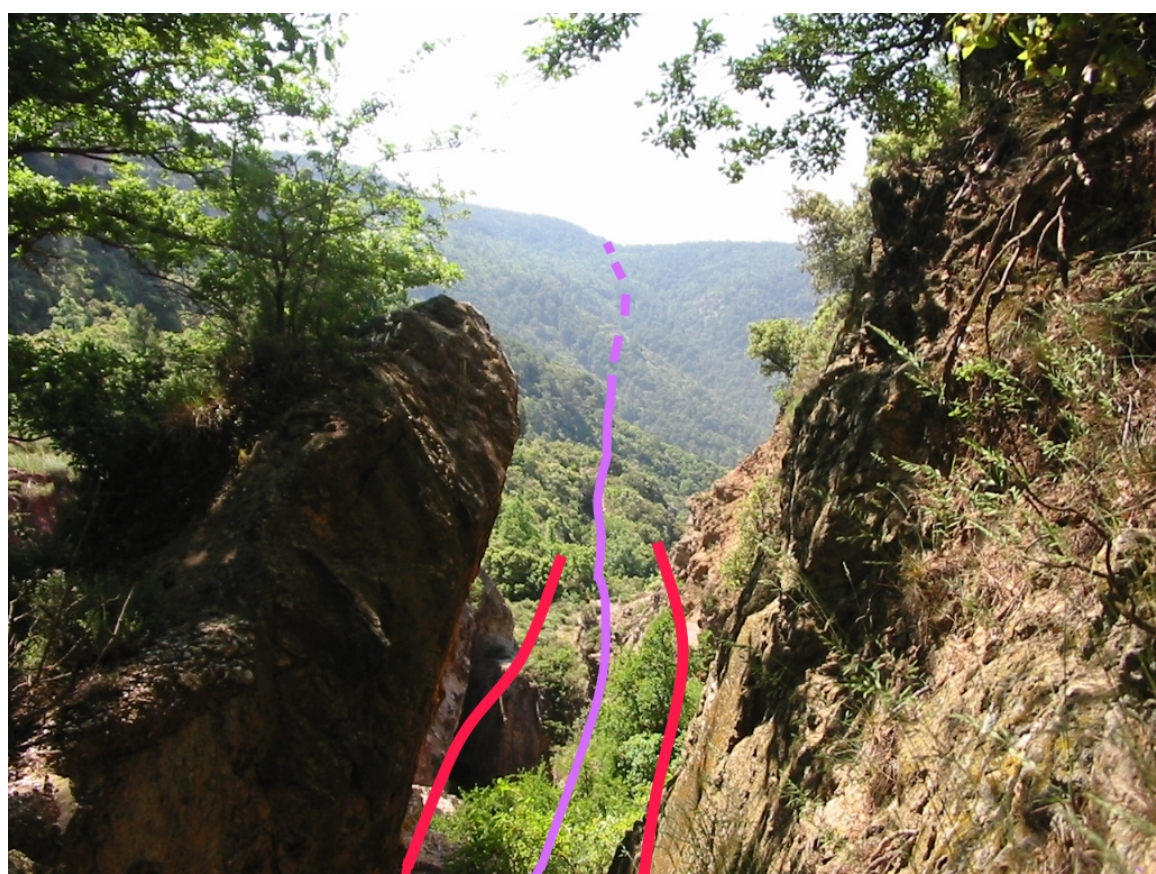

Esquema 1, fet sobre la FOTOGRAFIA 4. La línia violada indica la fractura (en traç seguit) que es fa evident a l'indret de I'aturada i la seva possible direcció cap el Coll de Rojals (en traç discontinuo).

Les línies vermelles indiquen el filó explotat a l’indret de l’aturada.

\subsection{Parada 10. PART INFERIOR DE L'EXPLOTACIÓ DE LA MINA ATREVIDA ("MALACATE"), (Monestir de Poblet, terme municipal de Vimbodí, comarca de la Conca de Barberà). (Full 417).}

Després de fer l'aturada anterior, cal fer un nou recorregut pel camí, que ara es va dirigint cap a Castellfollit. Tot i així, a uns $100-150$ metres del Coll de l'Àliga, cal agafar un corriolet, per tal d'anar a peu cap a la part inferior de l'explotació que hem vist a l'aturada anterior. Aquí, farem una nova aturada.

En aquest recorregut, hem anat trobant es materials esmentats a l'aturada anterior. Així, haurem vist per sota del nivells de calcolutites rogenques, el nivells de gresos i conglomerats del Buntsandsteim. Aquests materials són els que apareixen a l'indret de l'aturada. Tot i així, aquí es troben en contacte per falla amb els nivells pissarrencs i esquitosos paleozoic. I precisament, aquí es fa palesa la falla de la Mina Atrevida, que aquí ha estat explotada. Es tracta del conegut Filó Atrevida, del que hem parlat abans.

Entre els minerals presents, i que acompanyen a la BARITINA (extraordinàriament abundant), cal parlar dels següents: PLATA NATIVA (poc abundant), ARGENTITA (molt rara), CALCOPIRITA (rara), GALENA (força abundant), MARCASSITA, MILLERITA (poc abundant, però representativa i patrimonial), NIQUELINA (com I'anterior). PIRITA, RAMMELBERGITA

Xaragall.2015 n.4 | Recorregut de recerca geològica i mineralògica per les comarques de la Conca de Barberà i del Baix Camp: des de les masies de Poblet a la Pena, a la Mina Atrevida, al Pont de Castellfollit i a 
(poc abundant), SKUTTERUDITA (com l'anterior), ZEUNERITA (indicis), CALCITA, DOLOMITA i QUARS.

Com a minerals d'alteració, es troben, entre altres: GOETHITA (terrosa i limonítica), CERUSSITA (rara), HIDROCINCITA (rara), MALAQUITA, ANGLESITA (rara), ANNABERGITA (rara), CABRERITA (rara), ERITRINA (molt rara) i TIROLITA (rara). També es troben abundants mostres de dendrites de PIROLUSITA.

Finalment, cal dir que aquestes mineralitzacions i les seves explotacions, formen un important indret del nostre Patrimoni Mineralògic i Patrimoni Miner, respectivament.

\subsection{Parada11. BARRANC DE L'ARGENTERA, CAMí A CASTELLFOLLIT, (Monestir de Poblet, terme municipal de Vimbodí, comarca de la Conca de Barberà). (Full 417).}

Després de fer l'aturada anterior, cal retornar cap el camí per on estem circulant. Aquest ara es descendent i va baixant cap al paratge de Castellfollit. En creuar el Barranc de l'Argentera, podem fer una nova aturada. Així, des de l'anterior, haurem recorregut poc més de $1 \mathrm{Km}$, generalment en mal estat. L'aturada la podem fer a uns $100 \mathrm{~m}$ del barranc, seguint el camí que ens ha dut fins aquí.

En aquest recorregut, haurem tornat a trobar afloraments triàsics del Buntsandsteim. Tot i això, a l'indret de la present aturada estem sobre un aflorament dels materials paleozoics. Efectivament, hem tornat a trobar la fractura de la Mina atrevida. (fotografía 6).

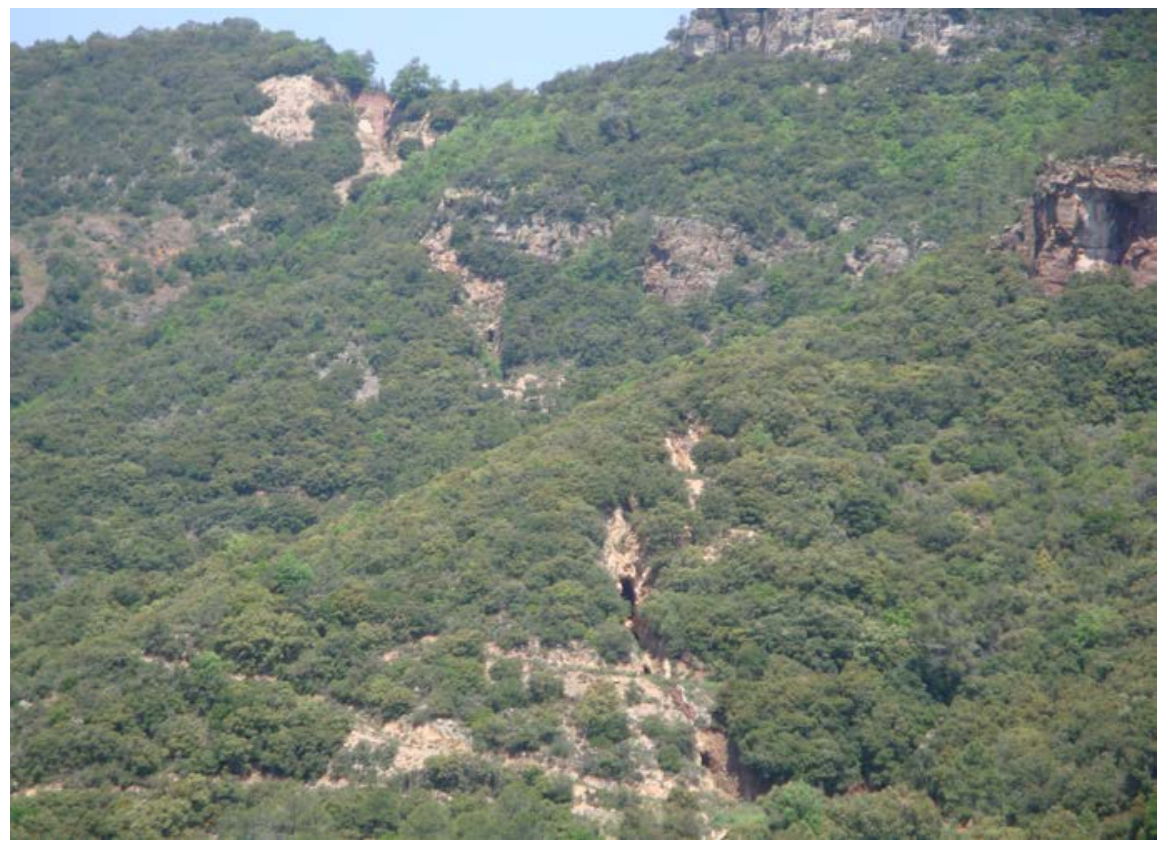

Fotografia 6. El Filó Atrevida (o Filó de la mina Atrevida). Es poden veure una sèrie d'explotacions realitzades des del Coll de I'Àliga, fins al fons del Barranc de l'Argentera

Xaragall.2015 n.4 | Recorregut de recerca geològica i mineralògica per les comarques de la Conca de Barberà i del Baix Camp: des de les masies de Poblet a la Pena, a la Mina Atrevida, al Pont de Castellfollit i a 
Igualment, es pot veure molt be la falla: a la dreta hi ha afloraments dels materials mesozoics del Triàsic (del Buntsandsteim, amb gresos, conglomerats i calcolutites rogenques; i del Muschelkalk, als cims, amb calcàries i dolomies); i a l'esquerra es veuen els materials paleozoics del Carbonífer (amb esquistos i diorites, fonamentalment).

Efectivament, des d'aquest indret, es pot fer una bona observació de la falla i de tota la zona minera de la Mina Atrevida. Així, es veu un important conjunt d'explotacions situades al llarg de la falla. Sobre aquesta fotografia, hem composat el següent ESQUEMA 2.

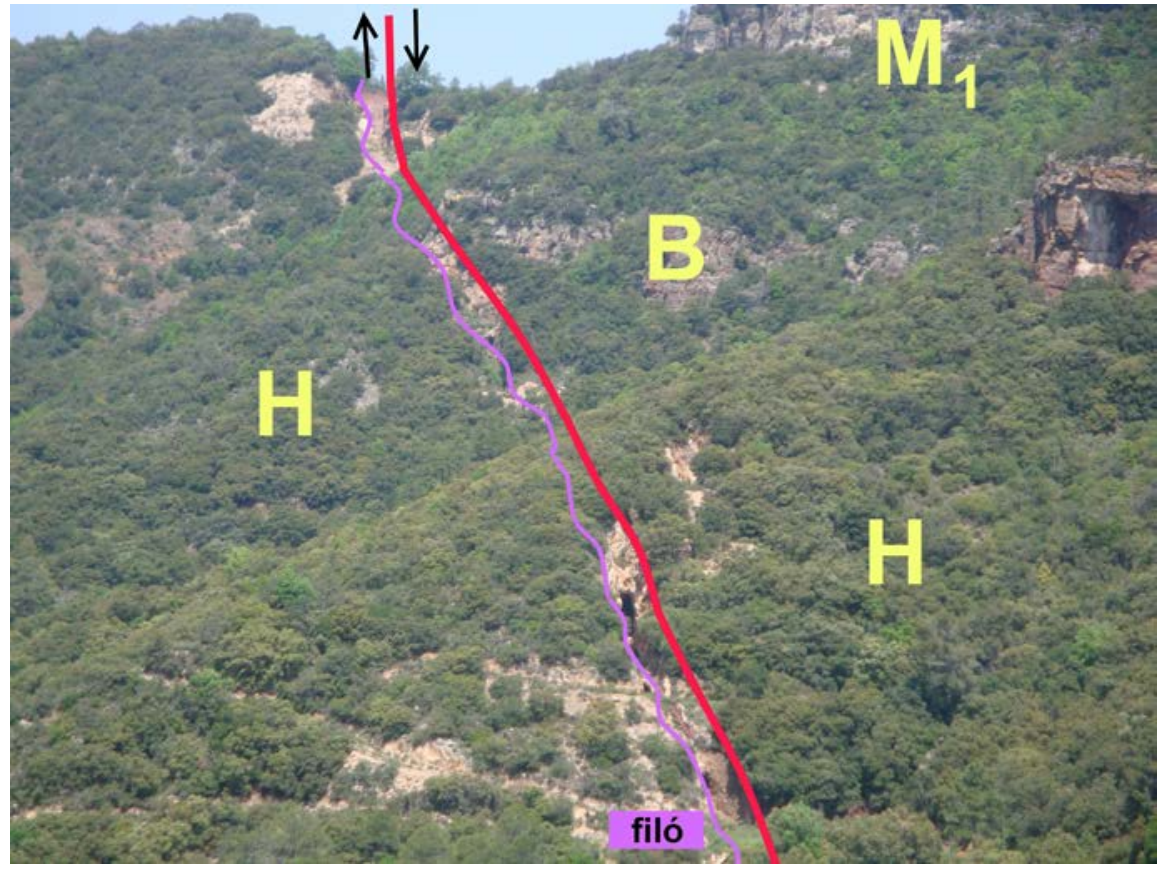

Esquema 2, fet sobre la FOTOGRAFIA 6. PARADA 11

En aquest esquema, es pot veure (en color vermell) la Falla Atrevida, i en color rosa la direcció del Filó Atrevida Les lletres indiquen:

H (materials del Carbonífer), B (materials del Buntsandsteim) i $\mathrm{M}_{1}$ (materials del Muschelkalk Inferior)

\subsection{Parada 12. PONT SOBRE EL BARRANC DE CASTELLFOLLIT, DE LA CARRETERA A PRADES, (Monestir de Poblet, terme de Vimbodí-Poblet, comarca de la Conca de Barberà). (Full 4i7).}

Des de la parada anterior, cal continuar baixant pel camí, que ara es dirigeix cap al paratge de Castellfollit. Així, seguint el camí pel Barranc de l'Argentera i posteriorment el Barranc de Castellfollit, arribarem a aquest paratge. En arribar-hi, cal fer l'aturada prop del pont de la carretera abans esmentada, sobre el barranc. Així, des de la parada anterior, haurem efectuat un recorregut proper als $8 \mathrm{Km}$. Tot i així, aquest tram del camí forestal no es troba en bon estat de circulació; possiblement, es millor tornar a l'inici del trajecte que hem fet, arribat a la PARADA 1. Després, ens caldrà anar al Monestir de Poblet, per tal d'agafar aquí la carretera $T$ - 700 (la qual es dirigeix a Prades). A uns 5 Km de Poblet, arribarem a l'indret de I'aturada.

Xaragall.2015 n.4 | Recorregut de recerca geològica i mineralògica per les comarques de la Conca de Barberà i del Baix Camp: des de les masies de Poblet a la Pena, a la Mina Atrevida, al Pont de Castellfollit i a 
Si hem seguit per camí forestal, en aquest recorregut hem anat circulant per entre els afloraments paleozoics ja esmentats a la parada anterior, entre els quals es troben abundants afloraments granodiorítics, els quals pertanyen a la Serralada Prelitoral Catalana. Tot i així, en aquest indret apareixen uns nivells detrítics (gresos i conglomerats) cenozoics, els quals formen part del Complex Al.luvial del Montsant.

És a dir, en aquest recorregut, hem retornat a la Depressió Geològica de l'Ebre. Així, en arribar a l'indret de la parada, es fa clarament palès aquest contacte entre els materials terciaris (de la depressió) situats per sota de la carretera, i entre els paleozoics (de la serralada), situats per sobre de la mateixa.

Per altra banda, des d'aquest indret, es pot veure com el cabdal del Barranc de Castellfollit disminueix sensiblement (fins a quasi desaparèixer), en passar d'una banda a l'altra del pont. El que succeeix, és que el barranc passa d'un unitat a l'altra, i es comença a trobar (per sota del llit fluvial) al nivells detrítics carbonatats de la Formació Margalef, i amb els sumiders càrstics desenvolupats en ella. Així, aquest cabdal, és el que dona lloc a bona part del corrent d'aigua que mena a la Font Major de I'Espluga de Francolí.

\subsection{Parada 13 - CONDICIONAL. MINA DE BARITA DEL TOSSAL DE LA BALTASANA, (termes de Prades i de Vimbodí-Poblet, comarques del Baix Camp i de la Conca de Barberà). (Full 445).}

Des de la parada anterior, cal anar des de Prades cap al NNE, tot seguint la carretera T-700. la qual es dirigeix cap a ponent. Després d'un llarg recorregut ascendent de poc més de $15 \mathrm{Km}$, s'arribarà al Coll de les Masies. Des d'aquest coll, cal agafar un camí per la dreta, que en uns $4 \mathrm{Km}$ s'apropa fins al Tossal de la Baltasana, on cal fer la present aturada, després de recórrer uns $20 \mathrm{Km}$ des de la parada anterior.

En aquest recorregut, es passarà per uns afloraments de granits i de granodiorites (que es troben a la diversos indrets. També haurem trobat uns afloraments del Carbonífer, constituïts per esquits, quercites i nivells calcosilicatats.

Tot $\mathrm{i}$ així, en arribar al Tossal de la Baltasana, es troben uns afloraments dels granits i granodiorites, coberts parcialment pels materials del Buntsandstein. Entre els afloraments de les roques granítiques i granodiorítiques, es fa clarament palesa una mineralització filoniana, la qual afecta també als materials triàsics del Buntsandstein.

Sobre aquestes mineralitzacions s' han desenvolupat unes activitats mineres, encaminades a I'aprofitament de la BARITINA. Amb ella, també es troben altres minerals, com són els següents: PIROLUSITA (dendrítica), CALCITA i QUARS.

En aquest indret va haver-hi una explotació minera, la qual es troba tapiada a l'actualitat. (fotografia 7). 


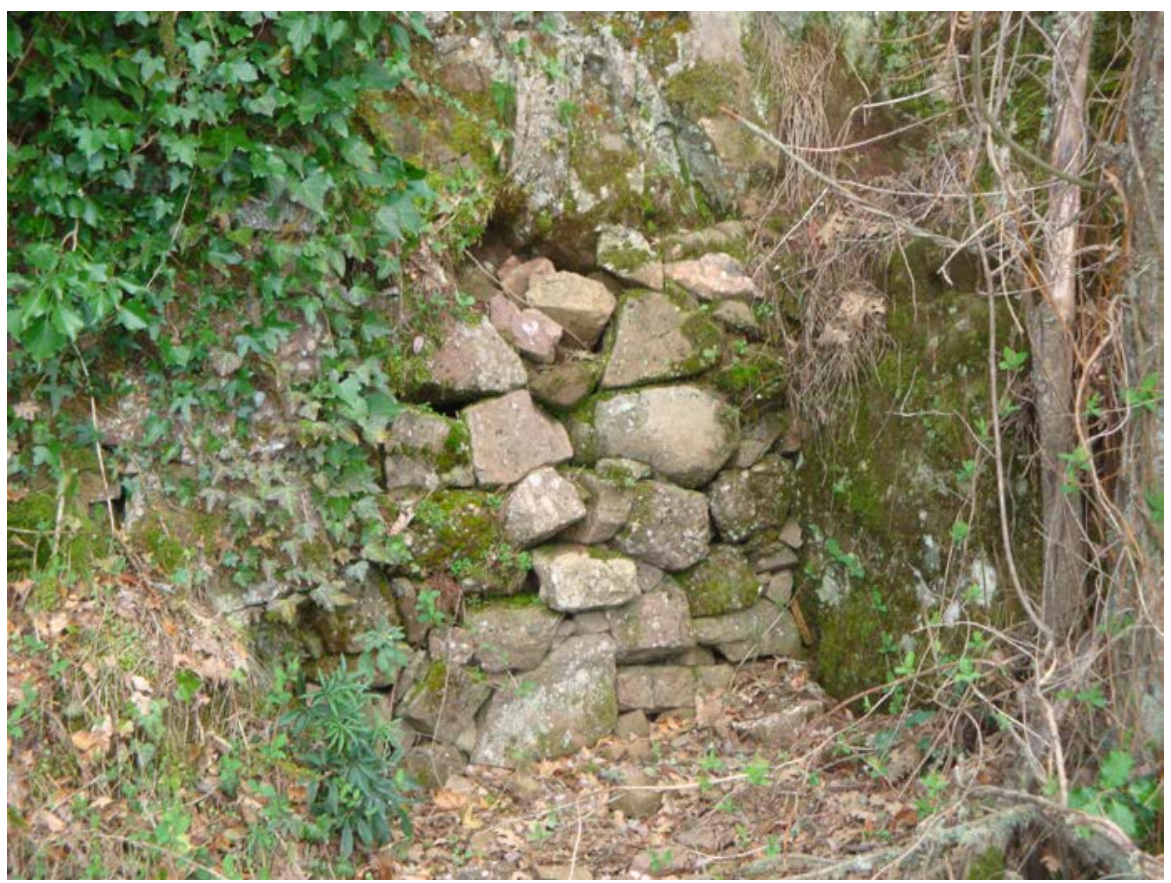

Fotografia 7. Antiga entrada a la mina, actualment tapada

\subsection{Parada 14. SAULONERA DEL CEMINTIRI DE PRADES, (terme municipal de Prades, comarca del Baix Camp). (Full 445).}

Després de realitzar l'aturada anterior, cal retornar a la carretera T-700, per tal de continuar cap al poble de Prades. Poc després de retornar a la carretera, sobrepassarem el trencall de Vilanova de Prades. Finalment, en arribar a Prades farem una nova aturada, a uns $11 \mathrm{Km}$ de la anterior.

En aquest recorregut, hem anat trobant els materials esmentats en el recorregut cap a l'aturada anterior. És a dir: haurem trobat afloraments dels materials del Carbonífer (amb esquists negres i quarsites), així com afloraments de granits i de granodiorites. Precisament, ara a l'indret de la present aturada, estem veient un d'aquests afloraments, de les esmentades roques granítiques i granodiorítiques

Així, en aquest indret ens trobem amb un aflorament de granodiorites. Aquestes han estat meteoritzades, transformant-se en "sauló". En aquest procés, el feldspat de les granodiorites, es transforma en caolinita, per l'acció de I'aigua meteòrica i de l'anhídrid carbònic. Així, la roca es transforma quasi totalment.

En aquest indret, questa roca el "sauló", ha estat explotada per a emprar-se com a material de construcció, com a àrid; tot i així, cal dir que no es la única explotació d'aquests materials que hi ha per aquests indrets. (fotografía 8).

Xaragall.2015 n.4 | Recorregut de recerca geològica i mineralògica per les comarques de la Conca de 


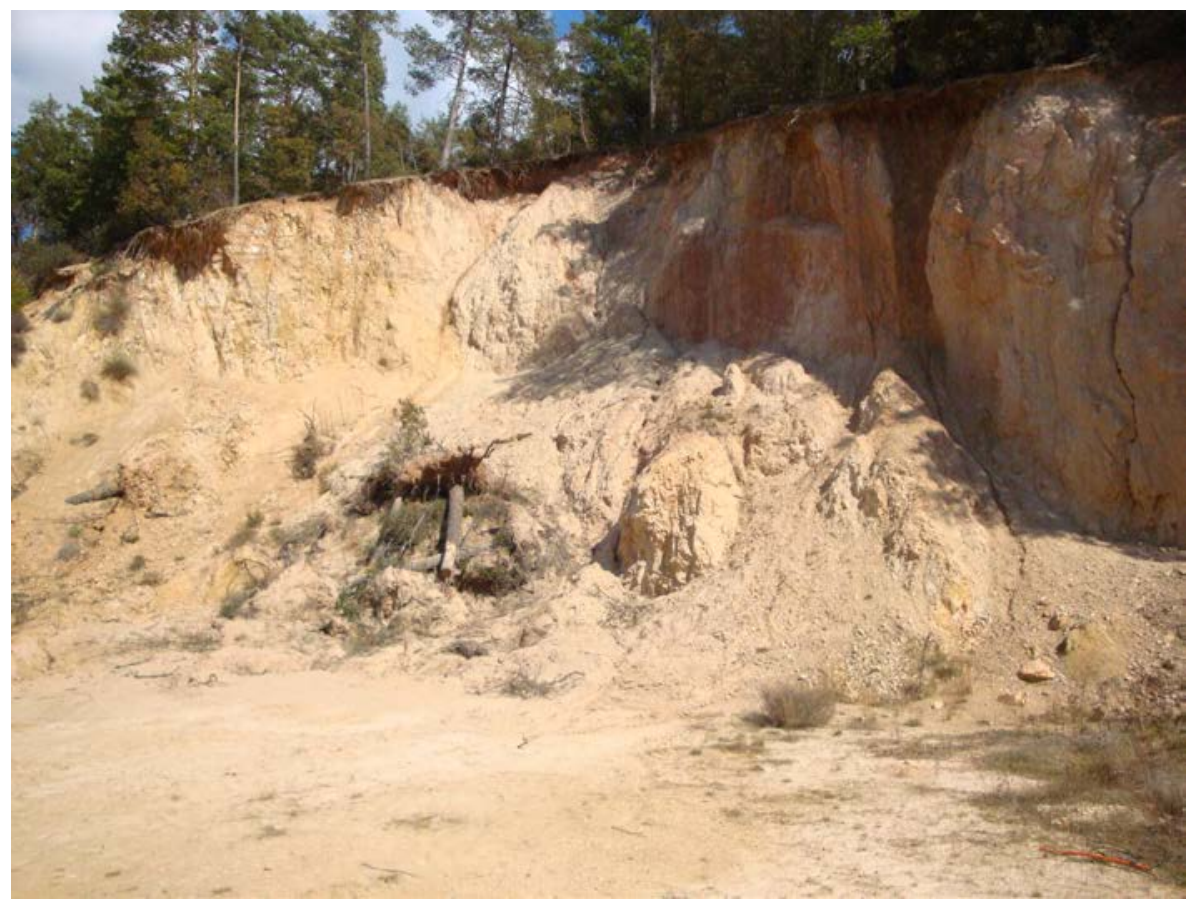

Fotografia 8. Pedrera de "sauló", del Cementeri de Prades

Per altra banda, en aquest indret, mirant cap a la dreta de la pedrera, es pot veure com els materials tenen una certa coloració superficial rogenca. Aquest color procedeix dels materials triàsics del Buntsandsteim, els quals cobreixen més a munt als materials paleozoics.

\subsection{Parada 15. LA PLAÇA MAJOR DE PRADES, (terme municipal de Prades, comarca del Baix Camp). (Full 445).}

Després de fer l'aturada anterior, sol ens cal continuar cap a Prades, per tal de fer la darrera aturada. Així, després d'un recorregut d'uns $2 \mathrm{Km}$ hi arribarem.

Inicialment, haurem trobat els materials esmentats a l'aturada anterior. Després, en arribar a la vila de Prades, es troben bons afloraments del nivells rogencs del Buntsandsteim, constituïts per gresos i lutites. Precisament, els primers s'han utilitzat per a la construcció de l'església parroquial, i la porta de les muralles, com es pot observar en aquesta aturada urbana.

Precisament, a l'indret on ara som, trobarem que aquests materials triàsics, són els que han estat utilitzats per a la construcció de l'Església i de moltes de les edificacions del poble de Prades, especialment de la plaça i de la porta d'entrada a la població, situada al costat de l'església.

Així veurem que per arreu hi ha carreus dels gresos rogencs del Buntsandstein, tot i que també es fan palesos els gresos clars. (fotografia 9).

Xaragall.2015 n.4 | Recorregut de recerca geològica i mineralògica per les comarques de la Conca de 


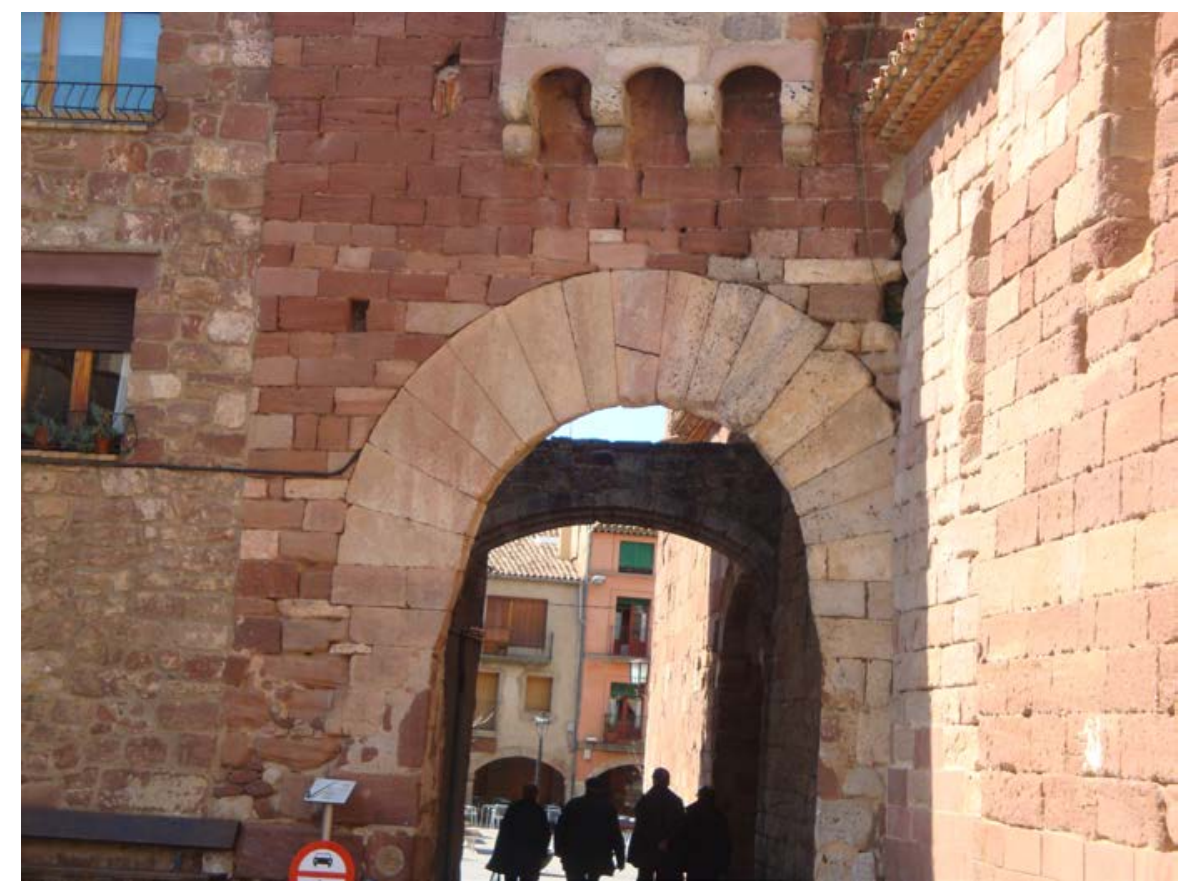

Fotografia 9. Porta de Prades i façana de l'església, amb carreus dels materials del Buntsandsteim.

Per altra banda, entre els materials triàsics del Buntsandsteim, que configuren bona part de l'església de Prades, es poden veure molt bons exemples d'estratificació creuada (de laminació creuada).

En aquest indret finalitza el recorregut de l'itinerari

\section{Bibliografia}

GUIMERÀ, J. et altri (1992).- Geologia (II), Història Natural dels Països Catalans, Vol.2, 547 pag. Enciclopèdia Catalana, S.A. Barcelona.

IGME (1973a).- Mapa Geológico de España (2a Serie). Explicación de la Hoja no 418 (Montblanc). Inst. Geol. Min. España. Minist. Indústria. Madrid.

IGME (1973b).- Mapa Geológico de España (2a Serie). Explicación de la Hoja no 446 (Valls). Inst. Geol. Min. España. Minist. Indústria. Madrid.

MARTínEZ, A. (2014).- Les Mines de Poblet i les aigües de I’Espluga de Francolí. Geolodia 2014, Tarragona. 8 pàgines. Poblet.

MATA-PERELLÓ, J.M. (1991).- Els Minerals de Catalunya. Arxius de la Secció de Ciències, t. XCIII, 442 pag. Institut d’Estudis Catalans. Barcelona.

Xaragall.2015 n.4 | Recorregut de recerca geològica i mineralògica per les comarques de la Conca de 
MATA-PERELLÓ, J.M. (1997a).- Recorregut de recerca geològica i mineralògica per les comarques de les Garrigues i de la Conca de Barberà. Inèdit, 14 pàg. Manresa.

MATA-PERELLÓ, J.M. (1997b).- Recorregut de recerca geològica i mineralògica per les comarques de la Conca de Barberà i de l'Alt Camp: des de Montblanc a Picamoixons, i des de I'llla a Valls. Algeps, sèrie $B, n^{\circ} 66.13$ pàg. Manresa.

MATA-PERELLÓ, J.M. (1997c).- Recorregut de recerca geològica i mineralògica per les comarques de la Conca de Barberà i de l'Alt Camp: des de l'Espluga de Francolí a Picamoixons, i des de l'llla a Valls. Algeps, sèrie $B, n^{0} 102.14$ pàg. Manresa.

MATA-PERELLÓ, J. M. (1999b).- Recerca Geològica i Mineralògica per la Conca de Barberà: des de Santa Coloma de Queralt a Sarral i des de Montblanc a Rojals. Inèdit, 16 pag. Manresa.

MATA-PERELLÓ, J. M. (1999a).- Recorregut de Recerca Geològica i Mineralògica per les comarques de les Garrigues, la Conca de Barberà i de l'Alt Camp: des de Vinaixa a Vimbodí, i des de la Pena a la Riba, Inèdit, 16 pag. Manresa.

MATA-PERELLÓ, J.M. (2000).- Recorregut de Recerca Geològica i Mineralògica per les comarques de la Conca de Barberà i de l'Alt Camp: des de Valls a Picamoixons i a l'Espluga de Francolí, Inèdit, 14 pag. Manresa.

MATA-PERELLÓ, J.M. (2002).- Recorregut de recerca geològica i mineralògica per la comarca del Baix Camp (amb filloles pel Priorat): des de Reus a l'Alforja, la Febró i Prades. Inèdit. 13 pàgines. Manresa.

MATA-PERELLÓ, J.M. (2003).- Recorregut de recerca geològica i mineralògica per la comarca de la Conca de Barberà: des de Montblanc a I'Espluga de Francolí i a la Mina Atrevida, Inèdit, 12 pag. Manresa.

MATA-PERELLÓ, J.M. (2004).- Recorregut de recerca geològica i mineralògica per la comarca de la Conca de Barberà: des de Montblanc a I'Espluga de Francolí i a la Mina Atrevida; i des de Vimbodí a Sarral i a Santa Coloma de Farners. Inèdit, 8 pag.. Manresa.

MATA-PERELLÓ, J.M. (2010).- Recorregut de recerca geològica i mineralògica per la comarca de la Conca de Barberà: des de les Masies de Poblet a la Mina Atrevida i al Pont de Castellfollit. Inèdit. 9 pàgines. Manresa.

MATA-PERELLÓ, J.M. (2011).- Recorregut de recerca geològica i mineralògica per la comarca de la Conca de Barberà i pel Baix Camp: de les Masies de Poblet a la Mina Atrevida, al Pont de Castellfollit i a Prades. Inèdit. 10 pàgines. Manresa.

RIBA, O. et altri (1976).- Geografia Física dels Països Catalans, Edit. Ketres, 254 pàgines. Barcelona.

Xaragall.2015 n.4 | Recorregut de recerca geològica i mineralògica per les comarques de la Conca de Barberà i del Baix Camp: des de les masies de Poblet a la Pena, a la Mina Atrevida, al Pont de Castellfollit i a 